\title{
An Analysis of the Academic Status of Students and Its Key Controlling Factors in a Newly-Built Local Medical College
}

\author{
Jun Li* \\ Medical College \\ Hubei University of Arts and Science \\ Xiangyang, China \\ 296 Long Zhong Road, Xiangyang City, Hubei Province \\ junlits@163.com
}

\author{
Shiying Liao \\ Medical College \\ Hubei University of Arts and Science \\ Xiangyang, China \\ 296 Long Zhong Road, Xiangyang City, Hubei Province
}

\begin{abstract}
To investigate the academic status of students and to analyze the trend of students' academic achievement in a new local college of medicine and probes into the key control factors that affect the students' academic failure. Academic cleaning, questionnaire investigation and interview were used to analyze the status of students' failure, college teaching management and students' management, and the descriptive analysis method was used to analyze the data. 1. Failure status. The number and failure rate of students in a medical school for the academic year 2014-2018 generally showed an upward trend, with the highest number in the next academic year 2017-2018. The failure rate of clinical medicine and nursing were 32.6 percent and 28.1 percent respectively. 2. Fail course. The first four degree courses were physiology, biochemistry and molecular biology, systematic anatomy, preventive medicine. 3. Major cause of failure. The main reasons for failure were that the learning methods were not correct and the knowledge points were more resistance, the teaching method of teachers were monotonous and boring, the experimental equipment were insufficient, the guidance of experimental teachers was not enough, the study room was not enough, and the management mode of students' education was not appropriate. The number of students transferred to major was too large. 4. Students' attitude to failing and teaching expectation. 88.5percent students should learn lessons and review them carefully after failing, and the reform of teachers' teaching methods expected by students in turn was curriculum integration, mixed type, MOOCs, case type, flipping class, Problem-based learning (PBL). The failure rate of students in a certain medical college was increasing. The failure of degree course was more serious, the students' learning method was impertinence, the degree course was difficult, the teaching is monotonous, and the teaching guarantee condition was insufficient. The main reason of failure was that the student management mode was not suitable and the ratio of students to teachers was too high.
\end{abstract}

Keywords—new local undergraduate medical college; academic status; failure; key control factors

\section{INTRODUCTION}

In recent years, the failure rate of college students has been increasing, and the problem of failing has attracted more and more attention. Some studies have shown that the failure of

Foundation Project: 2017 Provincial Teaching Research Project of Hubei Province "A study on the quality assurance systembased on clinical medical professionalcertification”. Higher letter of Education in Hubei Province 2018(12) (2017421) college students has become a serious obstacle to the quality of talent training and students' social and future development. It also reflects the idea of running a university, the construction of style of study, the quality of talent training and the level of management [1]. It has been 8 years since the establishment of a new local undergraduate medical college. Clinical medicine began to enroll in September 2010 and Nursing began to enroll in September 2012. In the past years, the number of students failing and the failure rate were on the rise. Through the analysis of the students' academic status and the questionnaire survey of freshmen and sophomores in a newly established local medical college, this study analyzed the changing trend of students' academic achievement, and probed into the key factors that affect the students' academic failure. It provides scientific basis for making key management and control measures to solve students' academic failure.

\section{PARTICIPANTS AND METHODS}

The students in clinical medicine and nursing were studied in a new local medical college. The methods of academic cleaning, questionnaire investigation and interview were used to investigate and analyze the status of students' failure and students' management. The method of academic clean-up was used in the academic year 2014-2018, and the students' grades were derived from the comprehensive educational administration system, and the academic analysis of different majors, semesters, grades, courses, failing grades, failure rates, and so on were carried out. The questionnaire was designed by ourselves, and 480 freshmen and sophomores were selected by cluster sampling method, which mainly included students' basic situation, learning motivation and learning status, to participate in community and extracurricular activities, failure status, teachers' teaching status, etc. 480 people should be investigated, and 441 effective questionnaires should be collected, and the response rate was 91.8 percent. Interview method were held in face-to-face teaching information feedback meeting of teachers and students, individual interview of students, interview of teaching supervision experts to understand the views of the students on the reasons of failure. 


\section{RESULTS}

\section{A. Base situation.}

The program number of students in the clinical medicine professional from 2010 to 2017 was 120 people. 55 students, 71 students and 21 students were transferred from other majors to grade $15 / 16 / 17$ respectively. The student management adopted the instructor, the teacher concurrently acts as the class teacher, and Class 16 students did not set up teacher in charge, by student cadres as class teachers.

\section{B. The analysis of the status of students failing in the academic year 2014-2018.}

TABLE I showed an overall upward trend in the number and failure rate of students in a medical school in the academic year 2014-2018, with the highest number of students in the academic year 2017-2018, with 289 failing students, the failure rate was 31.1 percent.

TABLE I. ANALYSIS OF STUDENTS' FAILURE IN THE ACADEMIC YEAR 2014-2018

\begin{tabular}{|c|c|c|c|c|c|c|c|c|c|}
\hline \multirow{2}{*}{ School year } & \multirow{2}{*}{ Number of cleaners } & \multirow{2}{*}{ Number of failing } & \multirow{2}{*}{$\%$} & \multicolumn{2}{|c|}{ Failing 10-20 credits } & \multicolumn{2}{|c|}{ Failing 20-30 credits } & \multicolumn{2}{|c|}{ Failing 30 credits or above } \\
\cline { 5 - 10 } & & & & Number & $\%$ & Number & $\%$ & Number & $\%$ \\
\hline $2017-2018-2$ & 930 & 289 & $31.1 \%$ & 80 & $8.6 \%$ & 25 & $2.7 \%$ & 11 & $1.2 \%$ \\
\hline $2017-2018-1$ & 834 & 238 & $28.5 \%$ & 70 & $8.4 \%$ & 22 & $2.6 \%$ & 4 & $1.1 \%$ \\
\hline $2016-2017-2$ & 819 & 184 & $22.5 \%$ & 48 & $5.9 \%$ & 10 & $1.2 \%$ & 5 & $0.6 \%$ \\
\hline $2016-2017-1$ & 749 & 210 & $28.0 \%$ & 40 & $5.3 \%$ & 10 & $1.3 \%$ & 5 & $0.7 \%$ \\
\hline $2015-2016-2$ & 953 & 187 & $19.6 \%$ & 32 & $3.4 \%$ & 7 & $0.7 \%$ & 4 & $0.9 \%$ \\
\hline $2015-2016-1$ & 702 & 126 & $17.9 \%$ & 27 & $3.8 \%$ & 5 & $0.7 \%$ & 8 & $1.1 \%$ \\
\hline $2014-2015-2$ & 745 & 149 & $20.0 \%$ & 32 & $4.3 \%$ & 6 & $0.8 \%$ & 8 & $1.1 \%$ \\
\hline $2014-2015-1$ & 745 & 175 & $23.5 \%$ & 39 & $5.2 \%$ & 9 & $1.2 \%$ & 6 & $0.8 \%$ \\
\hline
\end{tabular}

C. Analysis of students failing in the 2014-2018 academic year of clinical medicine and nursing specialty.

The failure rate of clinical medical students in the 20142018 academic year was the highest in the next academic year of 2017-2018, with 207 failing students and not pass rate was 32.6 percent. Among them, 79 failing students in grade 16 were the most serious. The proportion of failing students in the 2017-2018 first academic year was 40.1 percent, 109 failing students in the next academic year of 2017-2018, and the proportion of failing students was 52.7 percent, the worst grade for all previous students. See TABLE II.

TABLE II. ANALYSIS OF FAILURE ST ATUS OF ST UDENTS MAJORING IN CLINICAL MEDICINE IN ACADEMIC YEAR $2014-2018$

\begin{tabular}{|c|c|c|c|c|c|c|c|c|c|c|c|}
\hline \multirow{2}{*}{ School year } & \multirow{2}{*}{$\begin{array}{l}\text { Number of } \\
\text { cleaners }\end{array}$} & \multicolumn{8}{|c|}{ Clinical medicine grade } & \multicolumn{2}{|c|}{ Total } \\
\hline & & 10 & 11 & 12 & 13 & 14 & 15 & 16 & 17 & Number & $\%$ \\
\hline 2017-2018-2 & 634 & & & & & $30(14.5)$ & $52(25.1)$ & $109(52.7)$ & $16(7.7)$ & 207 & $32.6 \%$ \\
\hline 2017-2018-1 & 614 & & & $1(0.5)$ & $23(11.7)$ & $32(16.2)$ & $62(31.5)$ & $79(40.1)$ & & 197 & $32.1 \%$ \\
\hline $2016-2017-2$ & 601 & & & & $35(23.2)$ & $27(17.9)$ & $55(36.4)$ & $34(22.5)$ & & 151 & $25.1 \%$ \\
\hline 2016-2017-1 & 542 & & & $21(12.8)$ & $45(27.4)$ & $43(26.2)$ & $55(33.6)$ & & & 164 & $30.3 \%$ \\
\hline $2015-2016-2$ & 659 & & $18(11.1)$ & $37(22.8)$ & $45(27.9)$ & $42(25.9)$ & $20(12.3)$ & & & 162 & $24.6 \%$ \\
\hline 2015-2016-1 & 486 & & $25(24.0)$ & $36(34.6)$ & $34(32.7)$ & $9(8.7)$ & & & & 104 & $21.4 \%$ \\
\hline 2014-2015-2 & 527 & $8(7.2)$ & $27(24.3)$ & $36(32.5)$ & $36(32.4)$ & $4(3.6)$ & & & & 111 & $21.1 \%$ \\
\hline 2014-2015-1 & 527 & $19(14.3)$ & $45(33.8)$ & $47(35.3)$ & $22(16.6)$ & & & & & 133 & $25.2 \%$ \\
\hline
\end{tabular}

In the 2014-2018 academic year, the failure rate of nursing students was the highest in the next academic year of 2017-2018, with 64 students failing, and the failure rate being
28.1 percent. The number of students failing in the last academic year of 2017-2018 was 25 people, with a ratio of 60.9 percent. See TABLE III.

TABLE III. ANALYSIS OF FAILURE ST ATUS OF STUDENTS MAJORING IN NURSING IN ACADEMIC YEAR 2014-2018

\begin{tabular}{|c|c|c|c|c|c|c|c|c|c|}
\hline \multirow{2}{*}{ School year } & \multirow{2}{*}{$\begin{array}{l}\text { Number of } \\
\text { cleaners }\end{array}$} & \multicolumn{6}{|c|}{ Nursing medicine grade } & \multicolumn{2}{|c|}{ Total } \\
\hline & & 12 & 13 & 14 & 15 & 16 & 17 & Number & $\%$ \\
\hline 2017-2018-2 & 228 & & & & $15(23.4)$ & $24(37.5)$ & 25(39.1) & 64 & $28.1 \%$ \\
\hline 2017-2018-1 & 220 & & & $4(9.8)$ & $12(29.3)$ & $25(60.9)$ & & 41 & $18.6 \%$ \\
\hline 2016-2017-2 & 218 & & & $5(15.2)$ & $15(45.4)$ & 13(39.4) & & 33 & $15.1 \%$ \\
\hline 2016-2017-1 & 207 & & $7(15.2)$ & $7(15.2)$ & $32(69.6)$ & & & 46 & $22.2 \%$ \\
\hline 2015-2016-2 & 294 & $4(16.0)$ & $11(44.0)$ & $8(32.0)$ & $2(8.0)$ & & & 25 & $8.5 \%$ \\
\hline 2015-2016-1 & 216 & $5(22.7)$ & 11(50.0) & $6(27.3)$ & & & & 22 & $10.2 \%$ \\
\hline 2014-2015-2 & 218 & $20(52.6)$ & $17(44.7)$ & $1(2.6)$ & & & & 38 & $17.4 \%$ \\
\hline 2014-2015-1 & 218 & 23(54.8) & $19(45.2)$ & & & & & 42 & $19.3 \%$ \\
\hline
\end{tabular}




\section{Analysis of failing courses for medical students in the academic year 2014-2018}

Further analysis of the failed curriculum of students in the academic year 2014-2018. The failure rate of students ranked among the top five courses in each academic year. TABLE IV showed that the failure rates of the four academic years in physiology were among the top five, Followed by biochemistry and molecular biology, systematic anatomy, preventive medicine, medical introduction, pathology, histopathology, internal medicine, pharmacology, medical immunology, diagnostics. 8 courses were degree courses. Physiology, biochemistry and molecular biology were increasing year by year.

TABLE IV. ANALYSIS OF FAILURE COURSE OF ST UDENTS MAJORING IN CLINICAL MEDICINE IN ACADEMIC YEAR $2014-2018$

\begin{tabular}{|c|c|c|c|c|c|c|c|c|c|c|c|c|c|}
\hline \multirow[b]{2}{*}{$\begin{array}{c}\text { School } \\
\text { year }\end{array}$} & \multirow[b]{2}{*}{$\begin{array}{l}\text { Number } \\
\text { of } \\
\text { Cleaners }\end{array}$} & \multicolumn{12}{|c|}{ Name of courses Number (\%) } \\
\hline & & Physiology & $\begin{array}{c}\text { Biochemistry } \\
\text { and molecular } \\
\text { biology }\end{array}$ & Histopathology & Pathology & Pharmacology & $\begin{array}{c}\text { Preventive } \\
\text { medicine }\end{array}$ & $\begin{array}{c}\text { Medical } \\
\text { introduction }\end{array}$ & $\begin{array}{l}\text { Systematic } \\
\text { anatomy }\end{array}$ & $\begin{array}{c}\text { Cell } \\
\text { biology }\end{array}$ & $\begin{array}{c}\text { Medical } \\
\text { immunology }\end{array}$ & $\begin{array}{l}\text { Internal } \\
\text { medicine }\end{array}$ & Diagnostics \\
\hline $\begin{array}{l}2017- \\
2018-2 \\
\end{array}$ & 634 & 76(12.0) & 106(16.7) & $18(2.8)$ & & & & & $56(8.8)$ & $36(5.7)$ & & & \\
\hline $\begin{array}{l}2017- \\
2018-1\end{array}$ & 614 & 63(10.3) & $47(7.7)$ & & & & & $33(5.4)$ & 53(8.6) & $32(5.2)$ & & & \\
\hline $\begin{array}{l}2016- \\
2017-2\end{array}$ & 601 & $61(10.1)$ & $46(7.7)$ & & & & & $33(5.5)$ & $25(4.2)$ & & & $21(3.5)$ & \\
\hline $\begin{array}{l}2016- \\
2017-1\end{array}$ & 542 & $40(7.4)$ & $33(6.1)$ & & & $33(6.1)$ & & $24(4.4)$ & $26(4.8)$ & & & 21(3.9) & \\
\hline $\begin{array}{l}2015- \\
2016-2\end{array}$ & 659 & $42(6.4)$ & $36(5.2)$ & & & $36(5.5)$ & $23(3.5)$ & $24(3.6)$ & & & & & \\
\hline $\begin{array}{l}2015- \\
2016-1\end{array}$ & 486 & $28(5.8)$ & & & $20(4.1)$ & & $24(4.9)$ & & & & & $16(3.3)$ & $15(3.1)$ \\
\hline $\begin{array}{l}2014- \\
2015-2 \\
\end{array}$ & 527 & $28(5.3)$ & & $34(6.5)$ & 19(3.6) & & $28(5.3)$ & & & & $25(4.7)$ & & \\
\hline $\begin{array}{l}2014- \\
2015-1\end{array}$ & 527 & $18(3.4)$ & $57(10.8)$ & $32(6.1)$ & $37(7.0)$ & & $27(5.1)$ & & & & & & \\
\hline
\end{tabular}

\section{E. Analysis of influencing factors of freshman and sophomore students failing.}

TABLE V showed that 158 of the 441 students surveyed failed, accounting for 35.8 percent. The analysis of failure reasons showed that the main reason was that the learning method was not proper and the more learning resistance, which was 140 (31.8 percent) and 150 (34.0 percent) respectively. The vast majority of the students in the classroom were in a good state of study, 64 (14.5 percent) focused on listening to lectures, 326 (73.9 percent) seriously listening, but 51 (11.6 percent) were not in a state of study, lost their minds or even slept, played with their mobile phones and chatted, they did not have enough time for self-study. 52 students (11.8 percent) did not review at all after class, 384 students (87.1 percent) thought that teachers' teaching method had a great influence on the learning effect. Of the 299 students (67.8 percent), 304 (68.9 percent) thought the teacher's personality charm and poor PPT quality, the boring classroom teaching method had a great influence on the students' playing with mobile phones. 35.261.0 percent of students thought that the teaching conditions were inadequate, the experimental equipment were insufficient, the teachers' guidance was not enough, the study room was not enough, and no special endorsement was set up. The analysis of interviews showed that the mode of student education management and the number of students changing majors also played a certain role. All the students in each class were employed as part-time class a teacher in charge of a class, only students of the class of 16 were concurrently teachers of the higher grade students. The number of students transferred from other majors to clinical medicine was 71 people, and the number of students transferred to clinical medicine was the highest in the past years.

TABLE V. ANALYSIS OF INFLUENCING FACTORS ON FAILURE OF MEDICAL SCHOOL ST UDENTS (N=441)

\begin{tabular}{|c|c|c|c|}
\hline Item & Contents & Number & Ratio(\%) \\
\hline \multirow[t]{2}{*}{ Whether or not to fail } & Yes & 158 & 35.8 \\
\hline & No & 283 & 64.2 \\
\hline \multirow[t]{3}{*}{ Number of students failing } & One course & 96 & 22.8 \\
\hline & Two course & 38 & 8.6 \\
\hline & Three course and above & 24 & 5.4 \\
\hline \multirow[t]{5}{*}{ Failure cause } & Improper learning methods lead to low learning efficiency & 140 & 31.8 \\
\hline & Do not like the way teachers teach, do not want to listen to lectures & 44 & 10.0 \\
\hline & many and complex knowledge points in the course, great learning resistance & 150 & 34.0 \\
\hline & Failing to arrange time properly, no spirit in class & 81 & 8.4 \\
\hline & The examination paper is too difficult & 26 & 5.9 \\
\hline \multirow[t]{4}{*}{ Classroom learning state } & A preoccupied lecture & 64 & 14.5 \\
\hline & Normally, you can listen carefully & 326 & 73.9 \\
\hline & Most of the time wandering, even sleeping, playing mobile phones, chatting & 50 & 11.34 \\
\hline & No listening at al & 1 & 0.23 \\
\hline
\end{tabular}




\begin{tabular}{|c|c|c|c|}
\hline \multicolumn{4}{|c|}{ Cont. to TABLE V } \\
\hline weekly self-study hours(hour) & 0 & 52 & 11.8 \\
\hline & $1-6$ & 263 & 59.6 \\
\hline & $6-12$ & 82 & 8.6 \\
\hline & 12 and above & 44 & 10.0 \\
\hline \multirow[t]{2}{*}{ Teaching mode influence } & have & 384 & 87.1 \\
\hline & no & 57 & 12.9 \\
\hline \multirow[t]{5}{*}{ Reasons for playing cell phone in class } & Easy to learn to shoot PPT or search for related learning materials & 238 & 54.0 \\
\hline & The boring class was so that I couldn't help using my cell phone & 304 & 68.9 \\
\hline & Teacher's Personality charm PPTs Teaching style & 299 & 67.8 \\
\hline & I want to play when I see others playing & 86 & 9.5 \\
\hline & other & 57 & 12.9 \\
\hline \multirow[t]{5}{*}{ teaching facilities } & Insufficient experimental equipment, aging & 175 & 39.7 \\
\hline & Lab instructors are not enough. & 155 & 35.2 \\
\hline & Laboratory opening time is short, only for class time & 161 & 36.5 \\
\hline & Lack of study rooms and occupation & 208 & 47.2 \\
\hline & No place for special endorsement & 269 & 61.0 \\
\hline
\end{tabular}

F. The analysis of students' attitude towards failure, examination-oriented attitude and expectation on teaching methods.

TABLE VI showed most of the 390 students (88.5 percent) thought that they should learn lessons after failing review carefully and put an end to failure. A small number of students, 38 students (8.6 percent) lost their self-confidence and waiting for a supplementary examination. 251 students (56.9 percent) had a correct attitude and reviewed in advance, but a certain proportion of students 116 students (26.3 percent) hoped that the teacher should draw the scope and key points, and some students (16.8 percent) had a temporary cramming attitude.

The reform of teachers' teaching mode expected by students in turn was curriculum integration 302 (68.4 percent), mixed teaching 212 (48.0 percent), MOOC 199 (45.1 percent), case teaching 180 (40.0 percent), flipping class 140 (31.7 percent), problem-based learning (PBL) 84 (19.0 percent).

TABLE VI. ANALYSIS OF ST UDENTS' ATTITUDE TOWARDSFAILURE, ATTITUDE TO EXAMINATION AND EXPECT ATION OF TEACHING MET HODS IN A MEDICAL SCHOOL (N=441)

\begin{tabular}{|c|c|c|c|}
\hline Item & Contents & Number & Ratio(\%) \\
\hline Attitude towards failure & Learn the lesson, and carefully review the next exam. & 238 & 54.0 \\
\hline & Make up your mind, study hard and stop flunking & 152 & 34.5 \\
\hline & Regret not studying hard & 90 & 20.4 \\
\hline & Losing confidence, trying to escape & 9 & 2.0 \\
\hline & Open to accept, do not care, waiting for a supplementary examination & 29 & 6.6 \\
\hline Examination-oriented attitude & Take it seriously and review in advance & 251 & 56.9 \\
\hline & Hope the teacher's scope and focus & 116 & 26.3 \\
\hline & General temporary cramming, failing to pass the line & 73 & 16.6 \\
\hline & Random, not serious review, resigned to fate & 1 & 0.2 \\
\hline Expectation on teaching methods & Curriculum integration & 302 & 68.4 \\
\hline & Hybrid teaching & 212 & 48.0 \\
\hline & MOOC & 199 & 45.1 \\
\hline & Case teaching & 180 & 40.8 \\
\hline & Flipping classroom & 140 & 31.7 \\
\hline & PBL teaching & 84 & 19.0 \\
\hline
\end{tabular}

\section{DISCUSSION}

Academic achievement of medical students is a multidimensional comprehensive index reflecting the teaching guarantee, teaching quality, student management, style of study construction, quality control and so on. It is influenced by many factors.

\section{A. The trend of students failing}

From the results of this study, it can be seen that the overall failure rate of a medical college students in 2014-2018 academic year showed an upward trend, with the highest rate of $31.1 \%$ in the next academic year of 2017-2018. The overall failure rate of clinical medical students was higher than that of nursing students, with the highest failure rate of $32.6 \%$ in the next academic year of 2017-2018, and the most serious failure rate of 16 clinical medical students was in 2017-2018. Eight of the 12 degree courses ranked the top five in the previous year. Physiology, biochemistry and molecular biology showed an obvious upward trend year by year.

\section{B. An Analysis of the causes of students' failure}

This study found that the failure rate of freshmen and sophomores was as high as $30 \%$. The study of Ye Fangyun[2] showed that the failure rate of freshmen in a university was very serious, which can reach more than 50\%. The fundamental reason for the serious failure of freshmen lies in the students themselves. The freshmen relax seriously after entering the university. Loose management of university made some students with poor self-discipline relax their usual study and review. The first and second grades are often the most arduous periods for students to change their learning methods 
and to study medicine. They need to devote a great deal of energy to the study of knowledge in class. In this study some students (11.8 percent) spent less time on study than others. A considerable number of students responded to the exam mainly by making a surprise review before the exam. Fifty-one (11.2 percent) students were absent-minded in class, even sleeping, playing mobile phones. Surveillance experts visited the dormitory and found that some students spent all their spare time playing games and watching movies and television, drama, etc. This group of students is a key group of failing students

In this study, 140 student (31.8 percent) and 150student (34.0 percent) thought that the learning methods were incorrect and there were many knowledge points, and the learning resistance was the main reason for the failure. The failing rate of 8 degree courses ranked the top five in the previous five years, and physiology, biochemistry and molecular biology increased significantly year by year. 140 student (31.8\%) students showed that the learning methods were not correct, resulting in low learning efficiency.

The failing rate of clinical medicine majors was the highest in 16 grades, followed by 15 grades. In the case of the increase of the number of students and the insufficient increase of teachers and teaching conditions. 155 students (35.2 percent) reflect that the experimental teachers do not give enough guidance to the students. 9.7 percent thought that the experimental equipment was insufficient; the experimental conditions were not satisfied. 16-grade students were managed by senior cadres as class teachers, no teachers as class teachers, students' management experience and energy were insufficient, and management was loose. To some extent, it affects the students' style of study and the quality of their study.

384 students (87.1 percent) believe that teachers' teaching methods and personal charm have an impact on students' learning effect. The establishment of the college was relatively short. Most of the teachers were newly introduced Doctor and Master. The teaching experience was insufficient, the teaching research task was heavy, and the teacher's teaching attitude, teaching ability and level need to be further improved. Teachers' neglect of teaching and their personal development will have an impact on the quality of teaching and the reputation of the school [3].

\section{Measures to solve students' failure}

We should internalize Li De Shu Ren into all aspects of college construction and management; strengthen the construction of study style with moral educators [4-5]. Strengthen the institute system construction, standardize students' learning attitude and behavior, and stimulate students' learning autonomy and endogenous motivation. Strictly punish truancy, cheating and other violations of discipline, through strict academic assessment, fail to warn and urge students to work hard to complete their studies, away from online games and other undesirable hobbies. Teachers in charge of a class should combine professional education with student management.

Cultivating teachers' noble morality and high teaching level, encouraging teachers to actively explore flexible and changeable teaching methods, taking students as the main body and improving students' comprehensive quality as the basic purpose[4]. Adopting flexible and changeable teaching methods such as heuristic teaching, interactive and mixed teaching, stimulating students' learning fun and learning ability, and actively promoting curriculum integration. In order to improve the teaching quality as a whole, we should strengthen the construction of teaching guarantee conditions and strive funds for teaching through various channels further to improve the teaching hardware conditions, provide a good teaching platform for students' experimental practice teaching and selflearning, and promote the overall quality of teaching.

\section{CONCLUSION}

1. The failure rate of students in a certain medical college is increasing, especially in class 2016 majoring in clinical medicine, the failure of degree course is more serious.

2. The main reasons for failing are inappropriate learning methods, difficult degree courses, monotonous teaching by teachers, insufficient teaching guarantee conditions, unsuitable student management mode and high student-teacher ratio.

3. Strengthen the all-round management of teaching and students, and implement the student management model in which teachers also act as academic mentors of class teachers.

4. To promote actively the reform of teaching mode and teaching method such as curriculum integration, mixed teaching methods and MOOCs teaching methods, etc..

\section{REFERENCES}

[1] $\mathrm{Li}$ Qiu, $\mathrm{Yu}$ Qiang. An Analysis of the present situation and Countermeasures of the style of study in Universities from the situation of failing courses. Quality education in Western China 2018.2 DOI:10.16681/j.cnki.wcqe.201804088

[2] Ye Fangyun. Reasons and Strategies for the "Failure" of Freshmen. Journal of Jiamusi Vocational College, 2014, 11:26-27

[3] Sun Zhizhi, Wei Piao-piao. Study on the early warning mechanis m of failing students majoring in public administration. Journal of Central University of Finance and Economics, 2014 Supplement. 88-91

[4] Ministry of Education. Opinions on Accelerating the Construction of High-level Undergraduate Education and Improving the Ability of Personnel Cultivation.(Draft for comments)

[5] Chen Bao-sheng. Insist on taking undergraduate as the basis to push forward the four Reunification to build the First-class undergraduate Education with Chinese characteristics and World level.2018.6.21 http://www.moe.gov.cn.

[6] Wu Xinping, Chen Dongzhao. The causes and Countermeasures of freshmen failing the examination. Henan Education (Higher Education) 2013, 9:32-33 